
and Aromatic Plants

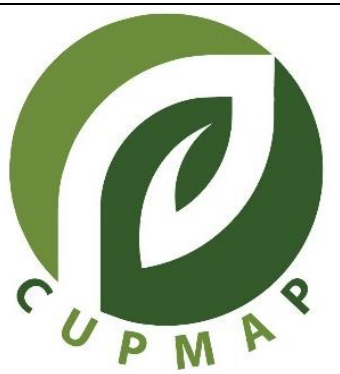

\title{
In vitro Antimitotic Activity of Gall Extract of Pistacia terebinthus
}

\author{
Bellifa NAZIM1 $^{*}$ (D), Benhaddou ISMAIL ${ }^{2}$ (D), Toumi HOUARI ${ }^{3}$ (D) \\ $\underline{\text { Norredine ZAKARIA }}^{4}$ iD, Ferkous HOUSSEM $^{5}$
}

${ }^{1}$ Department of Pharmacy, Pharmacognosy Laboratory, Faculty of Medecin, University of Djilali Liabes, 22000, Sidi Bel Abbes, ALGERIA

*Corresponding author: nazim.bellifa@univ-sba.dz

${ }^{2}$ Department of Pharmacy, Pharmacognosy Laboratory, Faculty of Medecin, University of Djilali Liabes, 22000, Sidi Bel Abbes, ALGERIA

${ }^{3}$ LRDP Pharmacology unit EHU Oran, University of ORAN, 31000, Oran, ALGERIA

${ }^{4}$ Department of Pharmacy, Analytical Chemistry Laboratory, Faculty of Medecin, University of Tlemcen, 13000, Tlemcen, ALGERIA

${ }^{5}$ Department of Pharmacy, Laboratory of Botany, Faculty of Medecin, University of Djilali Liabes, 22000, Sidi Bel Abbes, ALGERIA

\begin{abstract}
Pistacia terebinthus L. - turpentine tree - is a perennial flowering plant in the Mediterranean region, some aphids species induce the formation of galls in Pistacia terebinthus formerly called Carobs of Judea whose tannin content equals $60 \%$, used in traditional medicine as a stimulant, diuretic, astringent for the treatment of asthma and other respiratory and urological affections. In the present study, the antimitotic activity of Pistacia terebinthus galls was evaluated using meristematic cells of Allium cepa roots assay our results reveal that the methanolic extract decreased the root length and dividing cell number significantly after $96 \mathrm{~h}$ and compared to control $(\mathrm{p}<0.05)$ the mitotic index of extract at the concentration $4 \mathrm{mg} / \mathrm{ml} \mathrm{was}$ $31 \%$ and has significant activity near to the standard methotrexate. Overall, the methanol extract of $P$. terebinthus galls revealed the presence of the phytochemical's compounds such as gallic acid, caffeoylquinic acid, which affect plant mitosis and can be used as an antimitotic drug.
\end{abstract}

Key Words: Allium cepa, Antimitotic activity, Galls, Caffeoylquinic acid, Pistacia terebinthus

(C) CUPMAP. All rights reserved.

\section{Introduction}

Pistacia terebinthus L. (the Terebinth) is a deciduous tree or shrub from North Africa, referring to the Anacardiaceae, a fairly large family that includes 600 species and 70 genera (Bozorgi, 2013). The genus Pistacia has ten species, characterized by having alternate, pinnate leaves (Lin., 1984) and secretory cavities that contain resinous compounds. The plant owes its name to the oleoresin known as CHIO turpentine, it is the first turpentine known by Discords and this name was later extended to the oleoresin of conifers (Denoël., 1958). This tree is one of the components of the Mediterranean shrub, particularly in Algeria, where there are large stands, especially in the Tessala park, known 
as Betoum el Kiffan in Arabic and Hejji Kabyle (Lapie,1914).

Pistacia terebinthus produces a rich mixture of substances, including resin, essential oils, proteins, organic acids, sugars, flavonoids, and tannins. The leaves are often attacked by aphids, which stimulate the plant to form galls in the leaves. The gall contains a mixture of $60 \%$ resin, $36 \%$ tannins and $4 \%$ essential oil (Pulaj. 2019). Several studies have been engaged in different locations where the species grows in the wild to evaluate and compare its composition and biological proprieties, including as a bioherbicide and antifungal. antiinflammatory (Giner, 2002; Kordali, 2003; Kıvçak, 2004; Remila, 2015). While the antimitotic properties of this species have never been evaluated.

Some plant-derived compounds such as combretastatin, paclitaxel, colchicine, and vincristine are important antimitotic agents of cytotoxic drugs (Mukhtar, 2014). A large number of new drugs isolated from plants have been used for treating cancer. Most of these drugs are the secondary plant metabolites including phenolics and alkaloid (Calzada, 2020) These phytoconstituents are usually active against various types of cancers (Conforti, 2008).

The general principles of the mechanisms of mitosis are best and most easily studied in the actively growing regions of plants such as a shoot or root apex. Frequently, such studies involve the use of chemicals which modify the normal course of mitosis, In Allium cepa L. root tip model root system of plant cells, it is commonly used as a test for investigating environmental pollution factors, the toxicity of chemical compounds and evaluating potential anticancer properties. It is easy to make preparations of onion roots; they contain rather homogenous meristematic (Kuras, 2016). This study aimed to evaluate the composition of the methanol extracts of galls from Pistacia trebinthus and to test them for potential antimitotic activity on meristematic cells of Allium cepa roots.

\section{Material and Methods}

Pistacia terebinthus galls induced by aphids were collected by Dr. Bellifa Nazim in September and November in Tessala (35 $\left.{ }^{\circ} 16^{\prime} 22.9^{\prime \prime} \mathrm{N} 0^{\circ} 47^{\prime} 08.8 " \mathrm{~W}\right)$ state of Sidi Bel Abbes Western Algeria, the plant material was authenticated by Dr. Ferkous Houssem botanist of the pharmacy department Sidi bel abbes and Pr Alvarez R university Leon Spain, A specimen has kept in the herbarium of the department (Fig. 1).

Galls were dried and reduced into powder (100 g) separated into 3; Soxhlet extraction technique was adopted to get crude extracts using methanol as solvent. The extract obtained was concentrated in a rotary evaporator at low pressure and temperature to give crude methanol extracts, tannins were precipitated by ammoniac to give $48 \mathrm{~g}$ than the residue was extracted by chloroform according to the Stas Otto Method (Cortes, 2019). TLC was carried (DCM- MeOH-H2O, 77:13:10) to give gallic acid Rutin and caffeoylquinic acid, these compounds were determined using UV visible and Infrared spectroscopy (Jahangirian, 2011) using the spectral database (Bio-Rad) as well as a direct comparison of TLC with authentic samples (Sigma) available in our laboratory.

Ultraviolet-Visible spectroscopy: The chloroform fraction (7 g) was resolved by column chromatography (silica gel, $180 \mathrm{~g}$ ) using a step gradient of a DCM-MeOH solvent system to give carboxylic phenol acid. The evaluation of the anti-mitotic activity of the $\mathrm{MeOH}$ fraction was made as described by Sehgal et al. (2006) with modifications (Grant, 1982; Fiskesjo, 1988; Melappa, 2017). Using Allium cepa root meristematic cells which have been used extensively in the screening of drugs with a natural antitumoral origin (Fig 2). 


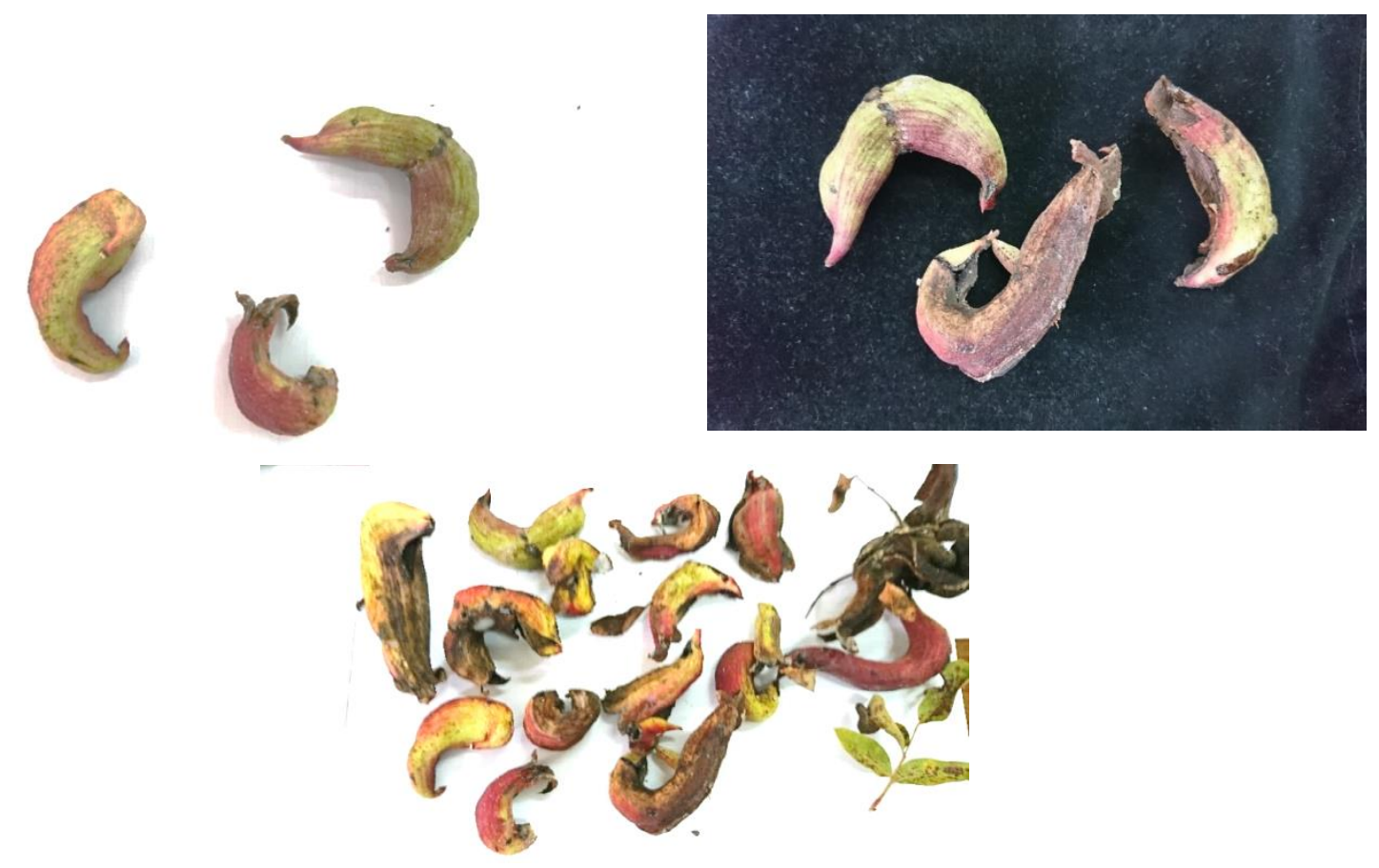

Fig 1 : Galls of Pistacia terebinthus

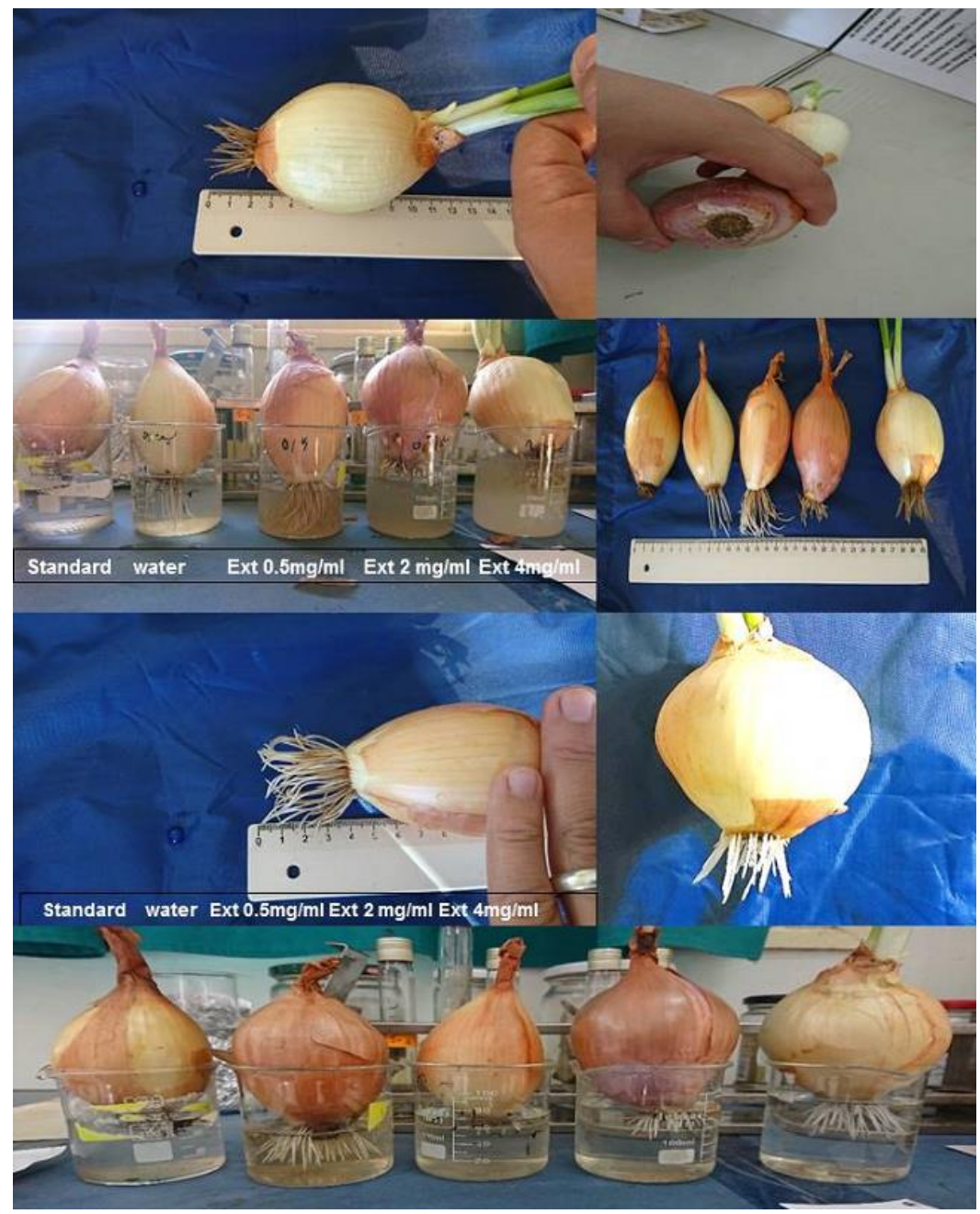

Fig 2 Antimitotic Activity after treatment of A. cepa root with different MeoH extracts of Galls 
A. cepa bulbs $(70 \pm 10 \mathrm{~g})$ were purchased from the local market and grown in beakers at room temperature for $48 \mathrm{~h}$ the bulbs with roots measuring $2-3 \mathrm{~cm}$ were transferred to beakers containing extracts at different dilutions $(0.5,1,2$ and $4 \mathrm{mg} / \mathrm{mL})$ in tap water.

A blank with water was used as control. Methotrexate was used as a standard control. All the groups were incubated at $25 \pm 2{ }^{\circ} \mathrm{C}$ for $96 \mathrm{~h}$ away from direct sunlight. The test samples were changed daily with fresh ones. The length of roots grown during incubation (newly appearing roots not included), root number and the mitotic index were recorded after $96 \mathrm{~h}$. After, the root tips were fixed with fixing the solution of acetic acid and alcohol. Squash preparations were made by staining the treated roots with acetocarmine stain and Giemsa and May Grünwald stain. For each root tip, the numbers of mitotic cells and total meristematic cells were counted manually in 3-5 fields of view using high resolution (100x) light microscopy (Leica). The mitotic index was calculated as

\section{Mitotic Index $=$ Number of dividing cells $/$ Total number of cells $x 100$}

\section{Results and Discussion}

In the present work, we displayed the strong anti-mitotic effect of methanol extract of the galls from Pistacia terebinthus towards Allium cepa root development; this model has been used for evaluating anti-mitotic activity (Raheel, 2017).

As already mentioned, aphids induce the host plant to secrete a range of phytochemical compounds such as polyphenols and terpenes, which under normal conditions, the plant would not generate this explains the difference in content between the leaf of $P$. terebeinthus and the extract of the galls, this can be explained by the interference of the metabolism of the plant and the aphid for example the pathways of development of auxin and cytokinin in plants. The high phenolic content helps explain the use of this plant in traditional medicine. Indeed, these compounds are widely known for their antiviral, antispasmodic, anti-tumor, hypocholesterolemic, anti-inflammatory, anti-hypertensive and antimicrobial activities. The extract was purified by TLC or CC and pure compounds were obtained: Hydroxamic acid and evaluated for antimitotic activity showed significant activity near to the standard. The $\mathrm{MeOH}$ extract of galls from Pistacia terebinthus presented strong and dose-dependent antimitotic activity in terms of decrease in mitotic index, mean root length and the number of dividing cells, the results were correlated with water used as a control in which $78 \%$ mitotic index was observed with actively dividing cells at various stages of mitosis (Fig. 3).

The results were analyzed based on mitotic index and are presented in Table 1 reflect the effect of various extracts on mitotic index. The methanolic extract of Pistacia terebinthus galls decrease the root length and dividing cell number significantly after $96 \mathrm{~h}$ and compared to control $(\mathrm{p}<0.05)$ as shown in the Table 1.

The mitotic index of $P$. terebinthus extract at the concentration $4 \mathrm{mg} / \mathrm{ml}$ was $31 \%$ and has significant activity proximate to the standard methotrexate $30 \% \quad(0.1 \mathrm{mg} / \mathrm{ml})$ Table1 shows the antimitotic activity of different extracts and methotrexate. Our results on these meristematic cells model corroborate previous works in which the mitotic index of extract decrease dividing cells number as root length was described Raheel, R 2017. And had an excellent antimitotic activity that was comparable to the activity of methotrexate. A maximum number of non-dividing cells were observed. 


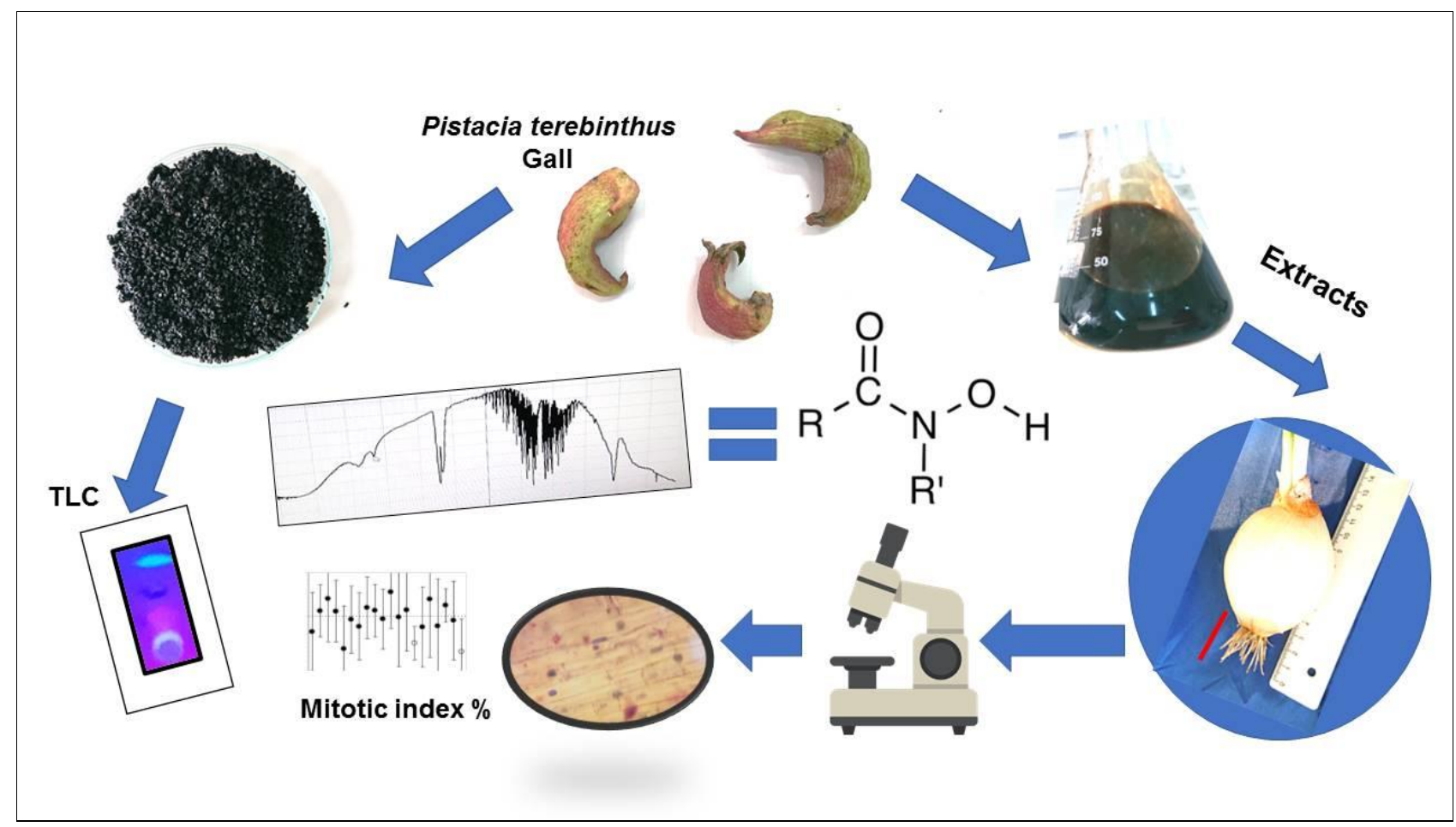

Figure 3. Dividing cells at various stages of mitosis

Table 1: The effect of different extracts on mitotic index

\begin{tabular}{|c|c|c|c|c|}
\hline $\begin{array}{c}\text { Extract } \\
\text { concentration } \\
(\mathbf{m g} / \mathbf{m L})\end{array}$ & $\begin{array}{c}\text { Mean root } \\
\text { Length } \\
(\mathbf{m m})\end{array}$ & $\begin{array}{c}\text { Number of } \\
\text { dividing cells }\end{array}$ & $\begin{array}{c}\text { Average } \\
\text { number of total } \\
\text { cells }\end{array}$ & $\begin{array}{c}\text { Mitotic } \\
\text { Index } \\
(\boldsymbol{\%})\end{array}$ \\
\hline Water & $45 \pm 1.5$ & 47 & 60 & 78 \\
0.5 & $40 \pm 2$ & 41 & 60 & 68 \\
1 & $40 \pm 1.2$ & 37 & 60 & 61 \\
2 & $30 \pm 2.3$ & 23 & 60 & 38 \\
4 & $20 \pm 1.6$ & 19 & 60 & 31 \\
Methotrexate & $15 \pm 1.5$ & 18 & 60 & 30 \\
$(0.1 \mathrm{mg} / \mathrm{mL})$ & & & \\
\hline
\end{tabular}

\pm Values are expressed as Mean \pm SD for triplicates

Cytotoxicity tests using in vivo plant systems, such as Allium cepa, are validated by several researchers, who have jointly conducted in vitro animal tests and the results obtained are similar. The Allium cepa test is one of the few direct methods of measuring cellular damage and analysis of cytotoxicity and genotoxicity because the roots are in direct contact with the extract often associated with microtubular disturbances.

Phytochemical characterization of the $\mathrm{MeOH}$ extract of Gall from Pistacia revealed the presence of the phytochemicals- Alkaloid, polyphenols, flavonoids, terpen, saponin glycosides and reducing sugars. In our study, it may be suggested that the extract may be acting through the pathway inhibiting tubulin that is required for DNA synthesis that arrest cell division. Methotrexate is known as an anticancer drug which competes with folic acid for the enzyme reductase Also Adamaskis et al had reviewed the antimitotic activity of Bisphenol and Taxol by immunofluorescence microscopy in meristematic root cells their study reported an elevation of tubulin 
acetylation on $A$. cepa root. caffeoylquinic acid is a potent moiety not only in the field of cancer therapy but also as a mutagenic agent. Among the various derivatives of carboxylic phenol acid, is considered as a potent anticancer agent. Scientists from different corners synthesized different phenolic acid moieties groups and have been evaluated as antimitotic agents. (Zhu, 2011).

Caffeoylquinic acids have attracted considerable interest recently because of their capacity to inhibit a variety of enzymes such as metalloproteases, some carboxylic phenol acid, such as caffeic acid have been used clinically for the treatment of cancer or iron-overload diseases. Much of the activities of these carboxylic phenol acids were thought to be due to their metal chelating properties (Witte, 2000; Jahangirian, 2011).

\section{Conclusion}

In conclusion, our results indicate the following: caffeoylquinic acid affects plant mitosis it maybe explains by disrupting microtubule organization. this result can explain the resistance of plants against aphids and open the possibility of exploiting P. terebinthus galls as a source of therapeutic agents.

\section{Acknowledgments}

The authors thank Dr. Benouala for his assistance and all the members of pharmacognosy Laboratory. Thanks, are also due to Pr Alvarez R for his contribution and assistance. UV-Vis spectra were recorded on a SHIMADZU 600 spectrophotometer in the range of $200 \mathrm{~nm}$ to $700 \mathrm{~nm}$ with $1 \mathrm{~nm}$ data interval. Scan speed was set to $400 \mathrm{~nm}$ min-1. All samples were prepared in methanol. Infrared spectroscopy. FT-IR spectra were recorded using a SHIMADZU IR Affinity-1S in the range of 500 to $3750 \mathrm{~cm}-1$.

\section{Conflict of Interest}

The authors have no conflicts of interest to declare.

\section{References}

1. Adamakis, Ioannis-Dimosthenis S.; Panteris, Emmanuel; Eleftheriou, Eleftherios P. 2019. "Tubulin Acetylation Mediates Bisphenol A Effects on the Microtubule Arrays of Allium cepa and Triticum turgidum." Biomolecules 9, no. 5: 185.

2. Bozorgi, M., Memariani, Z., Mobli, M., Salehi Surmaghi, M. H., Shams-Ardekani, M. R., \& Rahimi, R. 2013. Five Pistacia species (P. vera, P. atlantica, P. terebinthus, P. khinjuk, and P. lentiscus): a review of their traditional uses, phytochemistry, and pharmacology. TheScientificWorldJournal, 219815. https://doi.org/10.1155/2013/219815

3. Calzada, F., Merlin-Lucas, VI, Valdes, M. 2020 Métabolites secondaires et propriétés biologiques d'Annona muricata .Rev., Bras. Farmacogn. https://doi.org/10.1007/s43450-020-00012-w

4. Conforti, F., Ioele, G., Statti, G. A., Marrelli, M., Ragno, G., \& Menichini, F. 2008. Antiproliferative activity against human tumor cell lines and toxicity test on Mediterranean dietary plants. Food and chemical toxicology, 46(10), 3325-3332.

5. Cortes, Diego, Moreno, Laura, Párraga, Javier, Galán, Abraham et Cabedo, Nuria. 2019. Nouveaux médicaments inspirés des annonacées. Revista Brasileira de Fruticultura , 36 (spe1), 22-31. https://doi.org/10.1590/S0100-29452014000500003

6. Denoël A 1958 Matière médicale végétale (pharmacognosie). Presses Universitaires de Liège, 2e éd.

7. Fiskesjö, G. 1988. The Allium test-an alternative in environmental studies: the relative toxicity of metal ions. Mutation Research/Fundamental and Molecular Mechanisms of Mutagenesis, 197(2), 243-260.

8. Giner-Larza, E. M., Máñez, S., Giner, R. M., Recio, M. C., Prieto, J. M., Cerdá-Nicolás, M., \& Ríos, J. 2002. Anti-inflammatory triterpenes from Pistacia terebinthus galls. Planta Medica, 68(04), 311-315.

9. Grant, W. F. 1982. Chromosome aberration assays in Allium: A report of the US Environmental Protection Agency gene-tox program. Mutation Research/Reviews in Genetic Toxicology, 99(3), 273-291.

10. Jahangirian, H., Haron, M. J., Yusof, N. A., Silong, S., Kassim, A., Rafiee-Moghaddam, R., Peyda, M., \& Gharayebi, Y. 2011. Enzymatic synthesis of fatty hydroxamic acid derivatives based on palm kernel oil. Molecules (Basel, Switzerland), 16(8), 66346644. https://doi.org/10.3390/molecules16086634

11. Kıvçak, B., Akay, S., Demirci, B., \& Başer, K. 2004 Chemical composition of essential oils from leaves and twigs of Pistacia lentiscus, Pistacia lentiscus var. chia, and Pistacia terebinthus from Turkey. Pharmaceutical biology, 42(4-5), 360-366. 
12. Kordali, S., Cakir, A., Zengin, H., \& Duru, M. E. 2003. Antifungal activities of the leaves of three Pistacia species grown in Turkey. Fitoterapia, 74(12), 164-167.

13. Kuras M, Nowakowska J, Sliwinska E, Pilarski R 2016 Changes in chromosome structure, mitotic activity and nuclear DNA content from cell of Allium Test induced by bark water extract of Uncaria tementosa (Willd.) DC. Journal of Ethanopharmacology 107: 211-221.

14. Lapie G., et Maige A., 1914 La flore forestière illustrée de l'Algérie. Paris.p581

15. Lin TS, Crane JC, Ryugo K, Polito VS, Djong TM 1984 Comparative study of leaf morphology, photosynthesis and leaf conductance in selected Pistacia species. J Amer Soc Hortic Sci 109: 325-

16. Melappa, G., Cb, S., \& Channabasava, B. P. 2017. In vitro antimitotic, antiproliferative and GC-MS studies on the methanolic extract of endophytic fungi, Penicillium species of Tabebuia Argentea Bur \& K. SCH. Sch. Farmacia, 65, 301-309.

17. Mukhtar, E., Adhami, V. M., \& Mukhtar, H. 2014. Targeting microtubules by natural agents for cancer therapy. Molecular cancer therapeutics, 13(2), 275284. https://doi.org/10.1158/1535-7163.MCT-130791

18. NAZIM, B , HOUARI, T , ISMAIL, B . 2020. Ethnobotanical Survey of Some Plants Used in Tessala Region, Algeria. Current Perspectives on Medicinal and Aromatic Plants (CUPMAP) , 3 (1), 18-24 . DOI: 10.38093/cupmap.652708

19. Pulaj B, Mustafa B, Nelson K, Quave CL, Hajdari A. 2019 Chemical composition and in vitro antibacterial activity of Pistacia terebinthus essential oils derived from wild populations in Kosovo. BMC Complementary and Alternative Medicine. DOI: 10.1186/s12906-016-1135-8.

20. Raheel, R., Saddiqe, Z., Iram, M., \& Afzal, S. 2017. In vitro antimitotic, antiproliferative and antioxidant activity of stem bark extracts of Ficus benghalensis L. South African Journal of Botany, 111, 248-257.

21. Remila, S., Atmani-Kilani, D., Delemasure, S., Connat, J. L., Azib, L., Richard, T., \& Atmani, D. 2015. Antioxidant, cytoprotective, anti-inflammatory and anticancer activities of Pistacia lentiscus (Anacardiaceae) leaf and fruit extracts. European Journal of Integrative Medicine, 7(3), 274-286.

22. Sehgal, R., Roy, S., \& Kumar, V. L. 2006. Evaluation of cytotoxic potential of latex of Calotropis procera and Podophyllotoxin in Allum cepa root model. Biocell, 30(1), 9-13.

23. Witte, I., Zhu, B. Z., Lueken, A., Magnani, D., Stossberg, H., \& Chevion, M. 2000. Protection by desferrioxamine and other hydroxamic acids against tetrachlorohydroquinone-induced cyto-and genotoxicity in human fibroblasts. Free Radical Biology and Medicine, 28(5), 693-700.

24.Zhu, B. Z., Zhu, J. G., Fan, R. M., \& Mao, L. 2011 Metal-independent pathways of chlorinated phenol/quinone toxicity. In Advances in Molecular Toxicology (Vol. 5, pp. 1-43). Elsevier. 